\title{
Effects of Ethanol on Membrane Lipids III. Quantitative Changes in Lipid and Fatty Acid Composition of Nonpolar and Polar Lipids of Mouse Total Liver, Mitochondria and Microsomes Following Ethanol Feeding 1
}

JOSEPH N. MICELI, Department of Pharmacology, School of Medicine, New York University Medical Center, New York, New York 10016, and WILLIAM J. FERRELL، ${ }^{2}$

Department of Pathology. The University of Michigan, Ann Arbor, Michigan 48104

\begin{abstract}
The effects of ethanol on the total, nonpolar, and polar lipids of whole liver, mitochondria, and microsomes have been evaluated. Differences in the fatty acid composition of various lipid subclasses have been compared in control and ethanol treated mice. On the whole polyunsaturated fatty acids, especially arachidonic (20:4) and docosahexaenoic (22:6), were found to decrease. The significance of an enzymatic mechanism vs. a peroxidative mechanism to explain the results is discussed. Decreases also were observed in the ratios of arach-
\end{abstract}

${ }^{1}$ The research described herein was conducted while the authors were associated with the University of Detroit, Detroit, Mich. and represents part of the work submitted by J.N. Miceli in partial fulfillment of the requirements for the Ph.D. degree.

2 Author to whom reprint requests should be addressed. idonate/linoleate following ethanol feeding. These changes are thought to be associated with decreases in the activity of the chain elongation-desaturation system.

\section{INTRODUCTION}

Both the size and the number of rat liver mitochondria have been shown to be affected by ethanol (1). In addition changes in fatty acid composition have been associated with membrane stability (2-4). Thus, it would seem that ethanol may have an effect on membrane structure and function, and this effect may be on changes in lipid composition. Liver triglyceride (TG) levels are reported to be influenced by the amount of ethanol given and the duration of exposure $(5,6)$. On the other hand, Fallen et al. (7), found no increase in liver TG following the administration of ethanol. French et al. (8), studied the effects of ethanol on the important membrane constituents cholesterol

TABLE I

Per Cent Distribution of Nonpolar Lipid and Polar Lipid in in Total Liver, Mitochondria, and Microsomes, of Controla and Ethanol Fed Miceb

\begin{tabular}{|c|c|c|c|c|c|c|}
\hline \multirow[b]{2}{*}{ Lipid } & \multicolumn{2}{|c|}{ Total liver } & \multicolumn{2}{|c|}{ Mitochondria } & \multicolumn{2}{|c|}{ Microsomes } \\
\hline & Control & Alcohol & Control & Alcohol & Control & Alcohol \\
\hline \multicolumn{7}{|l|}{ NPL } \\
\hline TG & 60.4 & 38.6 & 48.7 & 33.8 & 40.5 & 11.9 \\
\hline DG & 11.7 & 10.6 & 22.6 & 16.8 & 14.1 & 13.0 \\
\hline $\mathrm{CE}$ & 21.6 & 45.4 & 22.3 & 46.4 & 40.4 & 64.1 \\
\hline $\mathrm{C}$ & 5.6 & 4.3 & 5.1 & 1.9 & 4.0 & 7.6 \\
\hline FFA & 0.7 & 0.8 & 1.1 & 1.0 & 1.0 & 2.3 \\
\hline $\begin{array}{l}\text { Remainder } \\
\text { PL }\end{array}$ & - & 0.3 & 0.2 & 0.1 & $-m$ & 1.1 \\
\hline CPG & 49.2 & 46.4 & 63.8 & 65.5 & 43.1 & 35.7 \\
\hline EPG & 26.6 & 21.8 & 28.2 & 19.6 & 42.7 & 18.2 \\
\hline DPG & 8.8 & 16.1 & 0.8 & 2.6 & 4.2 & 31.4 \\
\hline SPG & 5.1 & 2.3 & 0.8 & 3.5 & 3.3 & 4.9 \\
\hline CLPG & 4.0 & 7.8 & 2.2 & 0.7 & 1.8 & 5.9 \\
\hline $\mathrm{SM}$ & 3.6 & 1.1 & 1.1 & 4.0 & 2.3 & 2.8 \\
\hline Remainder & 2.7 & 4.1 & 1.1 & 4.1 & 2.6 & 1.1 \\
\hline
\end{tabular}

aValues taken from Ref. 19.

$\mathrm{b}_{\mathrm{NPL}}=$ nonpolar lipid, $\mathrm{TG}=$ triglyceride, $\mathrm{DG}=$ diglyceride, $\mathrm{CE}=$ cholesterol esters, $\mathrm{C}=$ cholesterol, $\mathrm{FFA}=$ free fatty acids, $\mathrm{PL}=$ polar lipid, $\mathrm{CPG}=$ choline phosphogly ceride, EPG $=$ ethanolamine phosphoglyceride, $\mathrm{DPG}=$ diphosphatidyl glycerol (cardiolipin), $\mathrm{SPG}=$ serine phosphogly ceride, $C L P G=$ choline ly sophosphoglyceride, and $\mathrm{SM}=$ sphingomyelin. 
TABLE II

Lipid Content of Total Liver Mitochondria and Microsomes from Control and Ethanol Fed Mice Lipid Wt (mg) ${ }^{\mathrm{a}}$

\begin{tabular}{lcccc}
\hline Tissue sample & TL & NPL & PL & Remainder $b$ \\
\hline Total liver & & & & \\
$\quad$ Control & 1549 & 805 & 720 & 24 \\
Alcohol & 1747 & 1200 & 540 & 7 \\
Wt change & +198 & +395 & -180 & -17 \\
$\quad$ Per cent of total & +12.8 & +25.5 & -11.6 & -1.1 \\
Mitochondria & & & & 65 \\
Control & 500 & 190 & 245 & 22 \\
Alcohol & 383 & 214 & 147 & -43 \\
Wt change & -117 & +24 & -98 & -8.6 \\
Per cent total & -23.4 & +4.8 & -19.5 & 31 \\
Microsomes & & & & 11 \\
Control & 416 & 174 & 211 & -20 \\
Alcohol & 316 & 133 & 172 & -4.8 \\
Wt change & -100 & -41 & -39 & -9.4 \\
Per cent of total & -25.1 & -9.8 & & \\
\hline
\end{tabular}

aWt are the total wt obtained from each group of 20 mice. TL $=$ total lipid, NPL = nonpolar lipid, and $\mathrm{PL}=$ polar lipid.

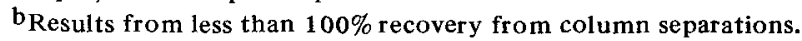

(C) and cholesterol esters (CE). No differences were found between control and ethanol fed animals.

In animals fed ethanol for 21 days, Fallen et al. (9) found no change in total liver polar lipids or ethanolamine phosphoglyceride (EPG), while Lieber et al. (10) observed increases in both of these under similar conditions.

Recently, evidence was presented for a decrease in the polyunsaturated fatty acids of rat liver mitochondria lipids following acute ethanol intoxication (11). Earlier findings (12) suggested that in ethanol-treated rats a peroxidative decomposition of liver mitochondria lipids may have occurred. A decrease in polyunsaturated fatty acids could be indicative of an in vivo peroxidative breakdown, since these acids would be most susceptible to this mechanism.

One cannot exclude the possibility of increased phospholipase activity following ethanol treatment. Recently evidence was presented showing an increase in plasmalogenase activity in mouse liver after ethanol feeding (13). Other data (14) suggesting that the polar lipid composition did not change after feeding ethanol would argue against the phospholipase hypothesis. However, in an earlier paper we

TABLE III

Effects of Ethanol on the Milligrams of Major Nonpolar Lipids and Polar Lipids in Mouse Liver ${ }^{\mathrm{a}}$

\begin{tabular}{|c|c|c|c|c|c|c|}
\hline \multirow[b]{2}{*}{ Tissue sample } & \multicolumn{3}{|c|}{ NPL } & \multicolumn{3}{|c|}{ PL } \\
\hline & $\mathrm{DG}$ & TG & $\mathrm{CE}$ & EPG & $\mathrm{CPG}$ & DPG \\
\hline \multicolumn{7}{|l|}{ Total liver } \\
\hline Control & 94 & 488 & 174 & 196 & 354 & 63 \\
\hline Alcohol & 127 & 463 & 545 & 118 & 250 & 87 \\
\hline Wt change & +33 & -25 & +369 & -78 & -104 & +24 \\
\hline Per cent of total & +2.1 & -1.6 & +23.8 & -5.0 & -6.7 & +1.5 \\
\hline \multicolumn{7}{|l|}{ Mitochondria } \\
\hline Control & 43 & 93 & 42 & 69 & 156 & \\
\hline Alcohol & 36 & 72 & 99 & 29 & 96 & \\
\hline Wt change & -7 & -21 & +57 & -40 & -80 & \\
\hline Per cent of total & -1.4 & -4.2 & +11.4 & -8.0 & -16.0 & \\
\hline \multicolumn{7}{|l|}{ Microsomes } \\
\hline Control & 25 & 71 & 70 & 87 & 89 & 9 \\
\hline Alcohol & 17 & 16 & 85 & 31 & 62 & 54 \\
\hline Wt change & -8 & -65 & +15 & -56 & -17 & +45 \\
\hline Per cent of total & -1.9 & -15.6 & +3.6 & -13.5 & -4.1 & +10.8 \\
\hline
\end{tabular}

a Values given are for each group of 20 mice. Only lipids which represented $10 \%$ or more of either subfraction are considered. See footnote $b$, Table I for abbreviations. 
TABLE IV

Changes in the Milligrams of Fatty Acids in Mouse Total Liver Lipids a

\begin{tabular}{|c|c|c|c|c|c|c|c|c|}
\hline & Fatty acid & $\mathrm{CE}$ & DG & TG & EPG & $\mathrm{CPG}$ & DPG & Totals \\
\hline \multicolumn{9}{|c|}{ Saturated } \\
\hline \multirow[t]{3}{*}{$14: 0$} & $\mathrm{C}$ & & 7 & & & 18 & 3 & 28 \\
\hline & A & & 10 & & & 10 & 7 & 27 \\
\hline & Per cent change $b$ & & +3.2 & & & -2.2 & +6.3 & $0^{\mathrm{c}}$ \\
\hline \multirow[t]{3}{*}{$16: 0$} & $\mathrm{C}$ & 49 & 18 & 97 & 59 & 66 & 8 & 297 \\
\hline & A & 68 & 32 & 85 & 23 & 42 & 17 & 267 \\
\hline & Per cent change & +10.9 & +14.9 & -2.4 & -18.4 & -6.8 & +14.3 & -1.9 \\
\hline \multirow[t]{3}{*}{$18: 0$} & C & & 5 & 19 & 33 & 25 & 3 & 89 \\
\hline & A & & 32 & 41 & 18 & 75 & 8 & 174 \\
\hline & Per cent change & & +28.7 & +4.5 & -7.6 & +14.1 & +7.9 & +5.5 \\
\hline \multirow[t]{3}{*}{$20: 0$} & $\mathrm{C}$ & & 7 & & & & & 7 \\
\hline & A & & 0 & & & & & 0 \\
\hline & Per cent change & & -7.4 & & & & & -0.4 \\
\hline \multicolumn{9}{|c|}{ Unsaturated } \\
\hline \multirow[t]{3}{*}{$16: 1$} & $\mathrm{C}$ & 13 & 4 & 41 & & 18 & 6 & 82 \\
\hline & A & 39 & 8 & 16 & & 5 & 3 & 71 \\
\hline & Per cent change & +14.9 & +4.2 & -5.1 & & -3.7 & -4.8 & -0.7 \\
\hline \multirow[t]{3}{*}{$18: 1$} & C & 60 & 31 & 155 & 32 & 76 & 8 & 362 \\
\hline & A & 250 & 30 & 135 & 8 & 50 & 7 & 480 \\
\hline & Per cent change & +109.2 & -1.1 & -4.1 & -12.2 & -7.3 & -1.6 & +4.7 \\
\hline \multirow[t]{3}{*}{$18: 2$} & $\mathrm{C}$ & 20 & & 128 & 10 & 7 & 29 & 194 \\
\hline & A & 85 & & 117 & 19 & 10 & 36 & 267 \\
\hline & Per cent change & +37.3 & & -2.2 & +4.6 & +0.8 & +11.1 & +4.7 \\
\hline \multirow[t]{3}{*}{$20: 4$} & C & & 10 & & 37 & 75 & 5 & 127 \\
\hline & A & & 3 & & 20 & 39 & 2 & 64 \\
\hline & Per cent change & & -7.4 & & -8.7 & -10.2 & -4.8 & -4.1 \\
\hline \multirow[t]{3}{*}{$22: 6$} & $\mathrm{C}$ & & 9 & & 10 & 32 & & 51 \\
\hline & A & & 0 & & 6 & 0 & & 6 \\
\hline & Per cent change & & -9.6 & & -2.0 & -9.0 & & -2.9 \\
\hline
\end{tabular}

a Values given are for each group of 20 mice and represent the average of four experiments. $\mathrm{C}=$ control, $A=$ alcohol; see footnote $b$, Table I for other abbreviations.

b Relative to the total amount (from Table III) of lipid subclass in question, i.e., cholesterol esters, diglyceride, ete, present in the control group. Only fatty acids representing $5 \%$ or more from each group are considered.

cThe percentages given in this column are relative to the control total lipid values from Table II.

suggested increased enzymatic hydrolysis of polar lipids to explain the results of incorporation of palmitate-1-14 $\mathrm{C}$ in mouse liver subcellular fractions (15).

In this article we examine the effects of chronic ethanol consumption on the levels of various nonpolar and polar lipids from mouse liver and also investigate changes in the composition of fatty acids associated with these lipids. Additional evidence in favor of the enzyme hydrolysis hypothesis will be presented by showing that the fatty acid composition of individual lipid classes is altered following ethanol ingestion for 21 days. These lipid changes and alterations in fatty acids were observed in the total liver, as well as the mitochondria and microsomes.

\section{MATERIALS AND METHODS}

\section{Animals}

Male Swiss-Webster mice weighing 24-26 g were used in this study. The control and alcoholic groups were maintained for 21 days on water and ethanol, respectively, as described previously (13); each group consisted of 20 animals. Subcellular fractions were prepared by ultracentrifugation (16). Histological comparisons, between sections of liver from control and alcohol groups, using Safranin and Sudan Black stains (17) showed that fatty livers had not been produced in the alcoholic mice.

\section{Lipid Extraction and Chromatography}

The procedures for lipid extraction, separation into nonpolar and polar lipid fractions, and thin layer chromatography to obtain individual lipid subclasses, are described elsewhere $(15,18)$. Quantitative lipid analysis was carried out, as previously described (19).

\section{Gas Chromatography}

Lipid subclasses representing $10 \%$ or more of the nonpolar lipid (NPL) and polar lipid (PL) were subjected to transesterification (20). Methyl esters were analyzed qualitatively by gas 
TABLE V

Changes in the Milligrams of Fatty Acids in the Mitochondrial Lipids of Mouse Livera

\begin{tabular}{|c|c|c|c|c|c|c|c|}
\hline & Fatty acid & $\mathrm{CE}$ & DG & TG & EPG & $\mathrm{CPG}$ & Totals \\
\hline \multicolumn{8}{|c|}{ Saturated } \\
\hline \multirow[t]{3}{*}{ 14:0 } & $\mathrm{C}$ & 1 & 5 & & 7 & 12 & 25 \\
\hline & A & 8 & 3 & & 2 & 5 & 18 \\
\hline & Per cent change $b$ & +16.7 & -4.6 & & -7.2 & -4.5 & $-1.4 \mathrm{c}$ \\
\hline \multirow[t]{3}{*}{$16: 0$} & $\mathrm{C}$ & 12 & 9 & 23 & 16 & 29 & 89 \\
\hline & A & 10 & 10 & 10 & 7 & 19 & 58 \\
\hline & Per cent change & -4.8 & +2.3 & -14.0 & -13.0 & -6.4 & -6.2 \\
\hline \multirow[t]{3}{*}{ 18:0 } & C & & 0.4 & 1 & 12 & 10 & 23 \\
\hline & A & & 9 & 13 & 3 & 27 & 52 \\
\hline & Per cent change & & +20.0 & +12.9 & -13.0 & +10.9 & +5.8 \\
\hline \multirow[t]{3}{*}{$20: 0$} & $\mathrm{C}$ & & & & & 8 & 8 \\
\hline & A & & & & & 0 & 0 \\
\hline & Per cent change & & & & & -5.1 & -1.6 \\
\hline \multicolumn{8}{|c|}{ Unsaturated } \\
\hline \multirow[t]{3}{*}{$16: 1$} & $\mathrm{C}$ & 1 & 1 & 6 & 0 & 11 & 19 \\
\hline & A & 7 & 3 & 0 & 2 & 0.2 & 12 \\
\hline & Per cent change & +14.3 & +4.6 & -6.4 & +2.9 & -6.9 & -1.4 \\
\hline \multirow[t]{3}{*}{ 18:1 } & $\mathrm{C}$ & 16 & 15 & 40 & 9 & 51 & 131 \\
\hline & A & 48 & 7 & 22 & 3 & 14 & 97 \\
\hline & Per cent change & +76.2 & -18.6 & -19.3 & -8.7 & -23.7 & -6.8 \\
\hline \multirow[t]{3}{*}{$18: 2$} & $\mathrm{C}$ & & 2 & 19 & 2 & 8 & 31 \\
\hline & A & & 0 & 14 & 4 & 7 & 25 \\
\hline & Per cent change & & -4.6 & -5.4 & +2.9 & -0.6 & -1.2 \\
\hline \multirow[t]{3}{*}{$20: 4$} & C & & 4 & 2 & 15 & 5 & 26 \\
\hline & A & & 0 & 1 & 6 & 13 & 20 \\
\hline & Per cent change & & -9.3 & -1.1 & -13.0 & +5.1 & -1.2 \\
\hline \multirow[t]{3}{*}{$20: 6$} & $\mathrm{C}$ & & 4 & & 4 & 19 & 27 \\
\hline & A & & 0 & & 1 & 0 & 1 \\
\hline & Per cent change & & -9.3 & & -4.3 & -12.2 & -5.2 \\
\hline
\end{tabular}

\footnotetext{
a Values given are for each group of 20 mice and represent the average of four experiments. $\mathrm{C}=$ control, $\mathrm{A}=$ alcohol; see footnote $\mathrm{b}$, Table $\mathrm{I}$ for other abbreviations.

b Relative to the total amount (from Table III) of lipid subclass in question, i.e., cholesterol esters, diglyceride, etc. present in the control group. Only fatty acids representing $5 \%$ or more from either group are considered.

${ }^{c}$ The percentages given in this column are relative to the control total lipid values from Table II.
}

liquid chromatography (GLC). Quantitative calculations were made using values for the various lipid classes present in normal mice, which we previously presented (19), and the values for ethanol fed mice reported in this paper (see Table I). GLC analysis was carried out using a Packard dual column Model 7800 instrument equipped with a hydrogen flame detector. A 6 $\mathrm{ft}$ glass column of either $14.5 \%$ ethylene glycol succinate-methyl silicone polymer (EGSS-X) coated on 100-120 mesh Gas Chrome P or $16 \%$ Apiezon $M$ on $60-80$ mesh Gas Chrome $S$ was used. Samples were run isothermally at $190 \mathrm{C}$. The carrier gas was nitrogen at an inlet pressure of $32 \mathrm{psi}$ and a flow rate of $140 \mathrm{ml} / \mathrm{min}$. Peak areas were calculated as the product of peak ht and the width at half peak ht. Percentages are given in terms of peak areas. Corrections for the detector response to the various fatty acids have been incorporated in the percentages. Fatty acid methyl esters were identified by retention times relative to methyl stearate
(18:0) and by cochromatography with known standards.

\section{RESULTS}

The overall effects of ethanol on the lipids of the total liver and subcellular fractions are given in Table II. These data show that ethanol fed mice had $12.8 \%$ more lipid in the total liver than the controls and that this resulted from an increase in NPL exceeding the loss in PL. Mitochondria, on the other hand, showed a loss of $23.4 \%$ total lipid (TL) which can be attributed to losses in PL. Microsomes also showed an overall loss of lipid $(25.1 \%)$, and this resulted from losses of both NPL and PL.

Table III shows that, in the total liver, the increase in NPL was due principally to $\mathrm{CE}$ which increased $300 \%$ ( $24 \%$ of the TL) and the loss of PL can be attributed to choline phosphoglyceride (CPG) and EPG, the losses in both cases representing more than 5\% TL. The loss of mitochondrial and microsomal PL also 
TABLE VI

Changes in Milligrams of Fatty Acids in the Microsomal Lipids of Mouse Liver ${ }^{a}$

\begin{tabular}{|c|c|c|c|c|c|c|c|c|}
\hline & Fatty acid & $\mathrm{CE}$ & DG & TG & EPG & $\mathrm{CPG}$ & $\mathrm{DPG}$ & Totals \\
\hline \multicolumn{9}{|c|}{ Saturated } \\
\hline \multirow[t]{3}{*}{$14: 0$} & $\mathrm{C}$ & & 1 & & 7 & & 0.4 & 8 \\
\hline & A & & 1 & & 1 & & 4 & 6 \\
\hline & Per cent change $b$ & & 0 & & -6.9 & & +40.0 & $-0.4^{c}$ \\
\hline \multirow[t]{3}{*}{$16: 0$} & $\mathrm{C}$ & 14 & 5 & 12 & 23 & 16 & 1 & 71 \\
\hline & A & 16 & 3 & 4 & 7 & 0 & 10 & 40 \\
\hline & Per cent change & +2.8 & +8.0 & -11.3 & -18.4 & -18.0 & +100 & -7.4 \\
\hline \multirow[t]{3}{*}{ 18:0 } & $\mathrm{C}$ & & 1 & 6 & 24 & 9 & 0.2 & 40 \\
\hline & A & & 3 & 0 & 5 & 20 & 3 & 31 \\
\hline & Per cent change & & +8.0 & -8.4 & -21.8 & +12.3 & +31.1 & -2.2 \\
\hline \multirow[t]{3}{*}{$20: 0$} & $\mathrm{C}$ & & 4 & & & & & 4 \\
\hline & A & & 0 & & & & & 0 \\
\hline & Per cent change & & -16.0 & & & & & -1.0 \\
\hline \multicolumn{9}{|c|}{ Unsaturated } \\
\hline \multirow[t]{3}{*}{$16: 1$} & $\mathrm{C}$ & 6 & 1 & 5 & & 0 & 1 & 13 \\
\hline & A & 6 & 1 & 1 & & 16 & 4 & 28 \\
\hline & Per cent change & 0 & 0 & -5.6 & & +18.0 & +33.3 & +3.6 \\
\hline \multirow[t]{3}{*}{$18: 1$} & $\mathrm{C}$ & 28 & 8 & 23 & 13 & 11 & 1 & 84 \\
\hline & A & 33 & 5 & 8 & 4 & 4 & 4 & 58 \\
\hline & Per cent change & +7.1 & -12.0 & -21.1 & -10.3 & -7.9 & +33.3 & -6.2 \\
\hline \multirow[t]{3}{*}{$18: 2$} & $\mathrm{C}$ & 10 & & 19 & 4 & 9 & 4 & 48 \\
\hline & A & 13 & & 2 & 5 & 0 & 20 & 40 \\
\hline & Per cent change & +4.3 & & -23.9 & +1.1 & -10.1 & +17.8 & -1.9 \\
\hline \multirow[t]{3}{*}{$20: 4$} & $\mathrm{C}$ & & 2 & & 6 & 21 & 1 & 30 \\
\hline & A & & $o$ & & 6 & 10 & 1 & 17 \\
\hline & Per cent change & & -8.0 & & 0 & -12.3 & 0 & -3.1 \\
\hline \multirow[t]{3}{*}{$22: 6$} & $\mathrm{C}$ & & 2 & & & 12 & & 14 \\
\hline & A & & 0 & & & 0 & & 0 \\
\hline & Per cent change & & -8.0 & & & -13.5 & & -3.4 \\
\hline
\end{tabular}

\footnotetext{
a Values given are for each group of 20 mice and represent the average of four experiments. $\mathrm{C}=$ control, $A=$ alcohol; see footnote $b$, Table $I$ for other abbreviations.

b Relative to the total amount (from Table III) of lipid subclass in question, i.e., cholesterol esters, diglycerides, etc. present in the control group. Only fatty acids representing $5 \%$ or more from either group are considered.
}

${ }^{c}$ The percentages given in this column are relative to the control total lipid values from Table II.

was due to CPG and EPG. Diphosphatidyl glycerol (cardiolipin) (DPG) increased in all cases, although in mitochondria this lipid constituted less than the selected $10 \%$ cutoff value (Table I). The surprisingly high percentage of DPG in the total liver and microsomes is not understood. The ester-phosphorous ratio (19) of this isolated lipid indicated a relatively pure fraction; and, therefore, the per cent values are thought to be real. Perhaps mouse liver is different with respect to DPG than other tissues analyzed to date. TG decreased in the total liver and subcellular fractions, with the greatest change occurring in the microsomes ( $15 \% \mathrm{TL})$.

Tables IV-VI give the amounts of fatty acids present in the major lipid subclass. Several observations stand out and deserve noting. The amount of arachidonic (20:4) and docosahexaenoic acids $(22: 6)$ decreased in all lipids containing the $m$ in the total liver, mitochondria, and microsomes of the ethanol treated mice, except in the CPG of mitochondria where 20:4 increased. No particular trend is evident in the changes with regard to linoleic acid (18:2). Overall we see that this fatty acid increased by ca. $5 \% \mathrm{TL}$ in the total liver and decreased by $1-2 \%$ in the mitochondria and microsomes respectively. Since the changes in 18:2 do not appear to be localized, the effect of ethanol to decrease the ratios of 20:4/18:2 (Table VII) is probably a general one rather than a specific effect on any particular lipid. Table IV shows that the large increase in $\mathrm{CE}$ in the total liver and mitochondria is primarily oleic acid (18:1).

\section{DISCUSSION}

The peroxidative hypothesis to explain decreases in polyunsaturated fatty acids following ethanol ingestion would appear to have little support in view of the work of others $(11,21)$. Thus it would appear that the effect is more on the enzyme level, as we suggested earlier (15). Evidence has been presented suggesting that the characteristic fatty acid composition of phospholipids is determined by redistribution of the fatty acids after the nitrogenous base has been 
attached (22). The activity of the fatty acylCoA:lysophosphatide transferases catalyzing this reaction recently has been shown to be enhanced with increased ethanol consumption (23). Thus, a mechanism of this type seems more likely than peroxidation. This is supported further when one examines the data in Tables V and VI. Here we see that, in both the mitochondria and microsomes of alcohol treated mice, a change has occurred in the fatty acid distribution of the major lipids. Our recent studies on the effects of ethanol on aldehy dogenic lipids (13) would also support this finding.

Examination of Tables IV-VI also reveals that significant increases in the stearic acid (18:0) content of various lipids has occurred in the total liver and mitochondria of ethanol fed mice. This is in contrast to others (11) who observed decreases in this fatty acid in rats fed ethanol. The reason for this discrepancy is not understood; however, it could be related to experimental conditions, most notably diet and the time duration of the experiments. Corn oil-fed rats and coconut oil-fed rats gave opposite results with respect to fatty acids found in the CPG and EPG following ethanol treatment (23).

A decrease in the arachidonate-linoleate ratio of liver lipids following alcohol ingestion also has been observed by others (24). Similar changes in heart lipids also were reported (25). Such decreases have been suggested to account for membrane stability (3) and mitochondria fragility (2). It has been suggested (26) that the decrease observed in liver mitochondria was due to decreases in the activity of the chain elongation-desaturation system which converts linoleate to arachidonate. Since liver CoA content is decreased markedly by ethanol (27), a decrease in the activity of the enzyme system seems a logical explanation.

\section{ACKNOWLEDGMENTS}

This investigation was supported in part by a research grant from the Licensed Beverage Industries, Inc., and by U.S. Public Health Service Grant HL-13361-01, 02.

\section{REFERENCES}

1. Kiessling, K.H., and L. Pilstrom, Acta Pharm. Tox. Kbh. 24:103 (1966).

2. DePury, G.G., and F.D. Collins, Chem. Phys. Lipids 1:1 (1966).

3. Hyashida, T, and O.W. Portman, J. Nutr. 81:103 (1963).

4. Holmer, G., and B. Tronier, Lipids 7:534 (1972).

5. Klastskin, G., H.M. Gewin, and W.A. Krehl, Yale J. Biol. Med. 23:317 (1951).

6. Mallov, S., Proc. Soc. Expt1. Biol. Med. 88:246 (1955).
TABLE VII

Effects of Ethanol on the Arachidonate-Linoleate Ratios in Lipids of Mouse Total Liver, Mitochondria, and Microsomes

\begin{tabular}{crrr}
\hline $\begin{array}{c}\text { Lipid } \\
\text { fraction }\end{array}$ & $\begin{array}{c}\text { Total } \\
\text { liver }\end{array}$ & Mitochondria & Microsomes \\
\hline Total lipids & & & \\
Control & 0.65 & 0.90 & 0.62 \\
Alcohol & 0.24 & 0.69 & 0.42 \\
Change & -0.41 & -0.21 & -0.20 \\
Nonpolar lipids & & & \\
Control & 0.67 & 0.28 & 0.07 \\
Alcohol & 0.01 & 0.07 & 0.00 \\
Change & -0.66 & -0.21 & -0.07 \\
Polar lipids & & & \\
Control & 2.43 & 2.20 & 1.47 \\
Alcohol & 0.94 & 1.30 & 0.68 \\
Change & -1.49 & -0.90 & -0.79 \\
\hline
\end{tabular}

7. Fallon, H.S., P.M. Gertman, and E.L. Kemp, Biochem. Biophys. Acta 187:94 (1969).

8. French, S.W., T.J. Ihrig, and R.J. Morin, Quart. J. Stud. Alc. 31:801 (1970).

9. Fallon, H.S., L.A. Persch, and G. Klatskin, Biochem. Biophys. Acta 98:470 (1965).

10. Lieber, C.S., D.P. Jones, and L.M. DeCarli, J. Clin. Invest. 44:1009 (1965).

11. Comporti, M., E. Burdino, and F. Raja, Life Sci. 10:885 (1971).

12. DiLuzio, N.R., and A.D. Hartman, in "Biological and Clinical Aspects of Alcohol Metabolism," Edited by V.M. Sardesai, Charles C Thomas, Springfield, Ill., 1969 , p. 133.

13. Ferrell, W.J., and J.N. Miceli, Comp. Biochem. Physiol. 41 B: 19 (1972).

14. Kiessling, K.H., and C.G. Lundquist, Scand. J. Clin. Lab. Invest. 1 8(Suppl. 92):80 (1966).

15. Ferrell, W.J., and J.N. Miceli, Quart. J. Studies on Alc. $31: 810(1970)$.

16. Hogeboom, G.H., W.C. Schneider, and G.E. Pallade, J. Biol. Chem. 172:619 (1948).

17. Barka, T., and P.J. Anderson, "Histochemistry Theory, Practice, and Bibliography," Harper and Row, New York, N.Y., 1965, p. 120.

18. Gilbertson, J.R., W.J. Ferrell, and R.A. Gelman, J. Lipid Res. 8:38 (1967).

19. Miceli, J.N., and W.J. Ferrell, Physiol. Chem. Phys. 4:131 (1972).

20. Morin, R.J., S. Bernick, J. Mead, and R.B. Alfin-Slater, J. Lipid Res. 3:432 (1962).

21. Hashimoto, S., and R.O. Recknagel, Expt. Mol. Pathol. 8:225 (1968).

22. Lands, W.E.M., and P. Hart, J. Biol. Chem. 240:1905 (1965).

23. Mendenhall, C.L., R.H. Bradford, and R.H. Furman, Biochem. Biophys. Acta 187:510 (1969).

24. French, S.W., and R.J. Morin, in "Biochemical and Clinical Aspects of Alcohol Metabolism," Edited by V.M. Sardesai, Charles C Thomas, Springfield, Ill., 1969 , p. 123.

25. Reitz, R.C., H. Helsabeck, and D.P. Mason, Lipids $8: 80$ (1973).

26. Shaw, G.P., S.W. French, T.J. Ihrig, T.T. Tonaka, and R.J. Morin, Lab. Invest. 24:447 (1971).

27. Ammon, H.P.T., C.-j. Estler, and F. Heim, Biochem. Phar macol. 18:29 (1969).

[ Revised manuscript received October 18, 1973] 